\title{
LITHUANIAN WRITERS AND THE ESTABLISHMENT DURING LATE SOCIALISM: THE WRITERS UNION AS A PLACE FOR CONFORMISM OR ESCAPE
}

\author{
Vilius Ivanauskas
}

\begin{abstract}
This article analyses how the changes in the dominant attitude of local Soviet writers were encouraged, screened or restricted by the Writers Union [WU] through mechanisms of planning, control and even through measures of creating a secure daily environment. The author looks at the tensions and conflicts between writers of different generations, observing less ideology in the younger generation than in their predecessors since the development and dissemination of national images among the declared values of communism were increasing. The union as a system covered both aspects - conformism and the escape (manoeuvre). Though the WU had a strong mechanism of control, it managed to ensure for the writers such a model of adaptation where even those, who were subject to restrictions, had a possibility of remaining within the official structure, through certain compromises, while actually avoiding involvement in dissident activities or samizdat publishing.
\end{abstract}

Introduction In August 1940 a group of Lithuanian intellectuals, most of whom were writers, went off to Moscow "to bring back Stalin's Sunshine", at the same time asking for Lithuania to be incorporated into the USSR. Forty eight years later in early June 1988 a few members of the local literary elite joined the initial Sajūdis Group and from thenceforth stood in the vanguard of the National Revival. These two historic moments, witnessing two contrary breaking points in history, when Lithuanian writers were active participants in events, naturally give rise to the question of how the status and role of writers and their relationship with the Soviet regime changed.

Giving more attention to the officially recognized writers and their institutional platform - the Writers Union of the Lithuanian SSR, it becomes reasonable to analyse how the dominating attitudes of writers were changing in the late Soviet period as compared with the early pre- 
vious period, what attitudes were like and how such positions were encouraged, screened or restricted by the Writers Union or closely related institutions through mechanisms of planning, control and daily security mechanisms. Considering examples, where in the late Soviet period some local writers published works transfused with ethnic and historical nostalgia, influencing considerably the mobilisation of national identity, and the situation where some writers either experienced restrictions because of unsuitable creative work, or devised an appropriate form of creation for both parties - the authorities and the public, it is relevant to analyse properly the impact of the WU on the activities of a writer. The union, which sought to ensure social status for writers, applied certain measures of control, trying to squeeze separate writers into the framework of socialist realism. Therefore, it is interesting to follow the development of this relationship at various periods, in particular in the post-Stalinist times, which in this article is termed 'the late Soviet period'. For example, applying the earlier mentioned anthropological description of the late socialist epoch ${ }^{1}$, introduced by the researcher of the Soviet period Alexei Yurchak, which is significantly different from other Soviet periods, the myth of the stagnant monolith of the Soviet system is disrupted, leading to methodological approaches for defining dynamic processes in the routine Soviet environment, gradually receding from official rituals and submerging into informal personal relations.

In discussing the role of the $\mathrm{WU}$, the impact of outside controlling institutions is assessed, as well as the changing socio-political context, paying attention to several generations of writers, specific features of which were an integral part of the Soviet periods in general. Relations between generations witnessed the dynamics of literature as such, and opportunities existed for the Writers Union to react to the changing environment, including the intensification of national processes, as well to protect or restrict authors, who did not fit properly within the framework of socialist realism.

The article uses data gathered by the author during a postdoctoral fellowship at the Institute of International Relations and Political Sciences of Vilnius University, in addition to material collected in Lithuanian and Russian archives, interviews with cultural figures, his dissertation defended in 2008 on the model of nomenklatura

${ }^{1}$ A. Yurchak, Everything Was Forever, Until It Was No More: The Last Soviet Generation (Princeton, 2005). 
activities, and qualitative methods, observations of other researchers, memoirs of witnesses of Soviet times, diaries, and so forth. ${ }^{2}$

The role of writers in the early Soviet period After the occupation of Lithuania in 1940, and later the restoration of the Soviet regime in 1944, intellectuals became involved in legalising the new order and were responsible for developing proper projections of the 'new subject', for the formation of collective memory and expectations; that is, they were supposed to become key instruments for the inculcating the doctrine of the Soviet regime. As stressed by one of the proponents, writers were granted a higher status than other cultural workers and were considered to be 'engineers of the soul'. The role of a writer may be considered as a metaphor of the cultural worker in Soviet times, and the Writers Union of those times as a reflection of cultural organisations supposed to give an organisational form to any activities of cultural workers. The more so that the role of the Writers Union in the public life of the republic was of great importance for defining the official circle of writers as well as the scope of their activities, not only providing a platform for prose writers and poets, but also covering a wider cultural environment - experts in the Lithuanian language, literary criticism, translators, directors or controllers of particular spheres of culture, who were entitled to membership of the Writers Union.

The primary task of the writers was related with the legitimisation of the new regime. In 1940, the famous writers Petras Cvirka, Salomejja Nèris, Antanas Venclova and others went to bring 'Stalin's sun' to legitimise the regime. With the start of the second Soviet occupation, Korsakas Korsakas, the executive secretary of the Writers Union mentioned in his speech at the meeting of writers on 26 September 1944: 'Our expedient and productive work is needed in many spheres of activities. First of all, it is expected by the Lithuanian people, who are longing for free and living speech from Lithuanian writers after three years of German occupation .... The Lithuanian countryside is currently involved in restoring the harm and damage done by the occupants to the peasants in the sphere of agriculture - a

2 This fellowship was funded by the European Union Structural Funds project 'Postdoctoral Fellowship Implementation in Lithuania' within the framework of the Measure for Enhancing Mobility of Scholars and Other Researchers and the Promotion of Student Research (VP1-3.1-MM-01) of the Program of Human Resources Development Action Plan. 
writer is expected here as well, who may personally depict, the great social reconstruction'. ${ }^{3}$ This portrayal of the status quo was related to the tradition of socialist realism in literature, which could not be overstepped and which always had to be coordinated with ideological principles, giving priority to class struggle and the rejection of bourgeois nationalism.

It is no coincidence that direct declarations of ideology in the activities to consolidate the regime and protect collectivisation processes brought in during the Soviet times, in developing a new subject, in fighting against national enemies, were appreciated and stimulated further not only at the beginning of the regime but also throughout the Stalinist period. It was very important to strike the right note and create, with great caution, works on topics which did not glorify the Party, Stalin, the introduction of collective farms, and such like directly. The storm of criticism reached even the 'Muscovites', who had proved their loyalty to the Soviet system time and time again. ${ }^{4}$ Actually all poets and writers published works glorifying the regime, even such talented authors as Neris and Cvirka were forced to demonstrate their loyalty. It should be noted that such declarative works helped to promote new leading writers, who demonstrated their loyalty through their biography and oeuvre (Aleksandras Guzevičius, Teofilis Tilvytis), and thus were praised by and involved in nomenklatura circles. In the post-war period, projections of the "new subject" as formulated by the USSR writers and other cultural workers were immediately transposed into the cultural area of the republic. Respectively, performances or films were produced on the basis of such creations (e.g. Boris Polevoi or Nikolai Ostrovskii) also encouraging the involvement of local authors in depicting the 'new subject' (Tilvytis or Gudaitis-Guzevičius) where the characters complying with communist values took pride of place.

Soviet Lithuania's Writers Union was established by writers, who participated in 1940 in the enforcement of the Soviet occupa-

3 'Tarybinių rašytojų pareigos ir uždaviniai', Tarybu Lietuva, Nr. 93, (1944 m. spalio 8 d.). See LMA, f. 34, ap. 1, b. 1, 1. 27.

${ }^{4}$ For example E. Mieželaitis' critique in 1946. In other words, a later biography of Mieželaitis witnesses that he considerably evolved, rejecting primitive Sovietism; when head of the WU in the 1960s he personally supported the development of Lithuanian philology. Otherwise, critics of literature in assessing his talent acknowledged that the power of his talent was too exaggerated by the system (interview with Vanda Zaborskaitè). 
tion and the annexation thereof, and who retreated to Russia during the years of the Nazi occupation (Cvirka, Neris, Liudas Gira, Jonas Marcinkevičius, Antanas Venclova, Kostas Korsakas, Jonas Šimkus, Eduardas Mieželaitis, Vladas Mozūriūnas, Juozas Baltušis) to bring back 'Stalin's sunshine'. These 'Muscovites' formed their own circle within a few years and used not only their wider social capital acquired in Moscow, but also the knowledge about the role of the Soviet writer that they gained in Moscow, the dominating topics and the rituals of public life compulsory for a writer. It is also relevant to notice hiow a rather active group in Moscow created Soviet Lithuanian literature and represented it in various gatherings of other USSR writers or cultural representatives. In 1944 after the restoration of the Soviet regime 'Muscovites' jointly with other writers formed a new Writers Union of the Lithuanian SSR, which highlighted the guidelines in the cultural area for disclosing not only the advantages of the new system, but also, participating in the construction of the historical memory, revealing the cruelty of the German invaders, and highlighting local war heroes and victims. ${ }^{5}$

The WU started its activities again in 1944 with over 60 registered members the core of which consisted of writers, who had returned from Moscow and other places in Russia. ${ }^{6}$ Some writers, who had remained in Lithuania during the period of the German occupation ${ }^{7}$ (e.g. Antanas Vienuolis-Žukauskas, Petras Vaičiūnas, Vincas MykolaitisPutinas, Kazys Boruta, Tilvytis, Ieva Simonaitytė and others, a total of 50 registered members), also joined the WU (they were provided with certain assistance ${ }^{8}$ ). The institutionalised WU became the key

${ }^{5}$ In his interview, V. Reimeris noted that the "identity of "Muscovites" (those who had retreated) was important for the post-war generation of writers and dominating for a certain period in the environment of writers. See: Interview with V. Reimeris.

${ }^{6}$ From the activities of the Writers Union, Tiesa, No 124 (3 Dec. 1944). LMA, f. 34 , ap. 1 , b. 1, 1. 27.

${ }^{7}$ It is mentioned in the review of the Lithuanian SSR WU by K.Korsakas in 1944 that during the years of German occupation the WU was liquidated, and writers had actually no support for their organised activities, were forced to perform other jobs, the premises of the WU were transferred to the German authorities. Ibid., 1. 46-47.

${ }^{8}$ During the post-war period, economic and everyday life issues were often addressed at the WU sessions, since 'according to comrade S. Čiurlioniene there is no creation without stimulation'. See: the minutes of the 9 Dec. 1944 meeting of the Kaunas branch of the Writers Union of the Lithuanian SSR at the city central library. Ibid., b. 2, 1. 19-20. 
platform gradually involving individuals granted or aspiring to writer status (e.g. in 1969, 119 members $^{9}$ ), creating at the same time the institutionalised and publicly recognised identity of a writer.

During the Stalinist period, intellectuals were supposed to avoid such activities and ideas, which might lead to their questioning the integrity of communist morals or allege the absence of ideology and disposition to cosmopolitism. The leading literary trend then was socialist realism (sotsrealizm), and writing was were supposed to reflect the ideological line propagating communist values, praising Soviet industrialisation, collectivisation and urbanisation, and the class struggle and bourgeois exploitation in the pre-war period. While soon after the liberation from the Germans, approximately in 1944 and 1945, the mission and the role writers in the system was described in more or less general terms, in 1946-1948 leaders in Moscow and locally defined the range of creation for writers. The mission of clearing literature at central level was taken up by Andrei Zhdanov, who suspended the poetess Anna Akhmatova and the satirist Zoshchenko, and created an atmosphere in the literary field 'against slaving for the West'. Kazys Preikšas, the secretary of the Central Committee of the Lithuanian CP, could be considered a counterpart of Zhdanov in Lithuania. In his speech at the general meeting of Soviet Writers of Lithuania in Vilnius on 1 October 1946, which was considered a turning-point, he referred to 'negative examples' of the improper implementation of this principle and an absence of political understanding (lack of attention to Soviet progress, positive attitudes towards the past, a lack of ideological spirit, passiveness), denouncing certain writers and poets, including some active young communists or persons, who had declared their loyalty to the Soviet regime. For example, he strongly criticized Mieželaitis: 'In the days, when decisive actions were taken for the fate of the Homeland, Mieželaitis found nothing better to do to encourage soldiers and fighters than pen some verse about a mare that was kissed by a lad "in the meadow of clovers, when his lassie proudly turned her nose away"... By this collection of non-ideological verse, "Tèviškès vejjas" (The Wind of Home), which he called a "collection of war time poems", Mieželaitis condemned himself to

${ }^{9}$ Though in other similar republics the membership was higher: in the Latvian WU, 119, the Armenian WU, 253, the Georgian, over 300, in the all-union WU, 6,860 members. See: RGALI.F.631, ap. 45, b. 165, 1. 2-18. The 1 Aug. 1969 statistical certificate about the Writers Union of the USSR. 
serious charges. 'His creative work is hostile to our creative people and reality; he is rolling down towards the nationalistic scrapheap'. ${ }^{10}$ The secretary also critically assessed the novel 'Dievų miškas' (The Forest of Gods) by Balys Sruoga: "What did Sruoga see in this horrible tragedy, called the German concentration camps? There he only saw common people, who were interested in some physiological functions. These are small-minded people. If Sruoga's book had been published, our enemies would have had good reason for saying that the Germans were right to keep such mean little people in concentration camps." Preikšas referred to the reliance of literature on the Party and the proletariat: 'In his famous article "The Organisation of the Party and the Literature of the Party" Lenin wrote that "literature shall follow the Party line. ... the socialist proletariat must raise up the principle of party literature, develop it further and implement it in life in the most complete and monolithic form'. He also criticised Juozas Paukštelis, Alfonsas Bieliauskas, and Eugenijus Matuzevičius in his speech, reminding his audience that writers were public figures, who should remain free from bribery and interests; a dose of criticism was addressed to the WU for improper education of young writers allowing for the spread of nationalistic approaches. Neris, Gira, Jonas Dovydaitis, Baltušis, Korsakas, Venclova, Vacys Reimeris and some others were indicated by Preikšas as positive examples. This speech was a clear signal that literary experiments are not allowed, as well as digressing from the party goals, since the delinquent will be suspended. In the early period, before the famous speech of Khrushchev in 1956 denouncing the cult of Stalin, all main institutional instruments were established in the environment of writers for defining the mission of writers and ensuring their high social status. Art and Science institutions were established, the role of cultural workers was defined, control mechanisms developed, e.g. critique in the daily 'Tiesa', and censorship by Glavlit. The range for the implementation of communist indoctrination was defined. The legitimisation policy of this 'new course' was in the main embodied by the new generation that left underground and succeeded in the years of war and the after-war period, and which may be defined within the entire scope of Soviet literature as demonstrating the position of ideologists.

${ }^{10}$ Objectives of Soviet Lithuanian literature. Report of Comrade K. Preikšas, the LCP(b) CC Secretary at the General Meeting of Soviet Lithuanian Writers in Vilnius on 1 October 1946. Literatūra ir menas (13 Oct. 1946), 1. 4. 
Changes in the post-Stalinist period Stalin's death in 1953, and the process of de-Stalinisation, which started with the famous speech of Khrushchev in 1956, inspired hopes for innovative creation. However, the post-Stalinist epoch as such experienced internal conflicts, and by creating more a open atmosphere was constantly reminding people that there was no time to relax. Such inconsistencies within the area of literature were obvious. On the one hand, the generation of Yevgeny Yevtushenko, Vasily Aksionov, Aleksandr Voznesensky and other 'shestidesiatniki' came out on the central level criticizing the Stalinist regime; Solzhenitsyn published his work 'One Day in the Life of Ivan Denisovich', the 'Novii Mir' journal under its editor Aleksandr Tvardovsky became the central axis for various yearnings. ${ }^{11}$ However, at the same time Boris Pasternak was denounced and expelled from the Writers Union for his novel 'Doctor Zhivago', published in Italy in 1957, when the author did not accept the remarks of the Soviet censorship. The absence of a consistent line in the postStalinist period was also marked by T. Rogers ${ }^{12}$, who mentioned several periods of thawing and estrangement in the area of culture, as in the famous speech referring to events in Poland in 1956 or the case of Pasternak, were soon followed by a decline in the thaw, while another wave was observed in 1959 after the USSR WU Congress and the appearance of new writers, which receded in 1962 when Khrushchev started attacking abstract painters, later reaching also writers (e.g. the trial of Joseph Brodsky in 1964).

The reaction to the 1959 congress of the Writers Union of the USSR was actively felt in the Lithuanian WU, where great attention was given to literary exploration and the new tasks raised before the Lithuanian writers. At the end of the 1950s and throughout the 1960s, the so-called post-war generation, which had been educated in Soviet Lithuania, started consolidating its position by supporting much more innovative creation. However, the existing general inconsistency of ideological boundaries and control determined that the new version of 'shestidesiatniki' in Lithuania was much more precautious than their colleagues in Moscow, although they were rather closely related through personal contacts (a conservative position ${ }^{13}$ ). In

${ }^{11}$ L. Koehler, 'Old Troubles of "The New World”, Russian Review, Vol. 32, No. 2 (1973), pp. 143-151.

12 T.F. Rogers, 'Trends in Soviet Prose of the "Thaw" Period', The Bulletin of the Rocky Mountain Modern Language Association, Vol. 22, No. 4 (1968), pp. 198-207.

13 A. Štromas, Laisvès horizontai, (Vilnius, 2001). 
the atmosphere of the thaw period a place was found for the poem 'Žmogus' (Man) by Mieželaitis, who was awarded the Lenin Prize, and the course of the stream of consciousness in the works of Bieliauskas and Mykolas Sluckis, also for the diverse creativity of Justinas Marcinkevičius, such as his story "Pušis, kuri juokèsi" (The Laughing Pine Tree), criticising formalism. All these works signalled support for the continuation of the socialist regime, even though, as mentioned in an interview by the literary critic Vanda Zaborskaite, belief in creating 'socialism with a human face' could be noticed in the works of the most talented authors of this generation.

Despite inconsistency in the ideological line, the Khrushchev period inspired hope and introduced considerably fewer restrictions in literature than had been the case after the war; simplified and rather primitive schemes in creative works were receding, even in the literature of socialist realism on rural topics, a clear transition was felt in comparison with the texts of Guzevičius and Jonas Avyžius. More attention then was given to the issues of the Lithuanian identity, though trying to follow the balancing position and avoid demonstrating a more open position. From 1960s to the 1980s, such persons as Just. Marcinkevičius, Alfonas Maldonis, Algimantas Baltakis, Algirdas Pocius, Vytautas Bubnys, and Mieželaitis took the leading posts in the Lithuanian WU and its publications.

With Brezhnev coming to power, and in particular after the events in Czechoslovakia, the hard-line regime 'put new restrictions' on culture. The tightening ideological policy of Moscow was demonstrated well inside the country through the activities the Security Committee of the USSR restricting the rights and freedoms of the intellectuals, writers or other prominent actors. It is worth mentioning here the trials of Andrei Siniavskii and Vladimir Bukovskii and other figures for their anti-Soviet activities. ${ }^{14}$

The Security Committee lead by Yuri Andropov regularly informed the USSR CC authorities about individuals involved in unsanctioned activities and the sanctions imposed against them. ${ }^{15}$ By the end of the 1960 s, there was a period of ideological tightening that was closely related to the change in leadership of the CC of the USSR and the situation in international relations, leading to support by the party authorities for ideologically-minded intellectuals, and the formation

${ }^{14}$ RGALI, USSR Security Committee note of 7 Jan. 1972 to the Central Committee of the CPSU, f. 89 , op. 25, d.15. fos. 1-2.

${ }^{15}$ P. Medvedev, Andropov (Moscow, 2006). 
of the contradictory position of conservative 'shestidesiatniki' - in restricting the unduly open activities of the coming generation (modernists) or other upstart writers, but tolerating their work expressed in Aesopian language. The ambiguity of this particular relation in the official channels may be analysed by assessing the specific features of the late Soviet period.

Specific features of the late Soviet period Most intellectuals willing to remain at the top in the Stalinist period were supposed to demonstrate obvious favour for the Soviet system, and avoid risky creative ideas. Moreover, all key instruments were created in this period for the implementation of communist indoctrination. Meanwhile the Khrushchev period should be considered as a transitional or grey zone, moving into the real late Soviet period where the Soviet system was more an inherited reality than an ideological or progressive value. However, despite the thaw context, it lacked clear direction, imposing at the same time certain restrictions. For example, the encouragement of innovation could be noticed in the area of literature around the 1960s, and at the same time the dismissal of the members of staff from Vilnius University's Department of Lithuanian Philology, including the rector of the University, J. Bulavas in 1958-1961. The distinction of the Khrushchev period is significant from the point of view of new expectations and the assumptions for larger diversity than in schematic Stalinist art. Recognising the Brezhnev period as a revival in the tightening of the regime, it is important to understand that intellectuals retained their previous expectations and this formed a gap, gradually retreating from visions for renovating the system and introducing alternative ideological and different manifestations of otherness, which, while not necessarily in opposition to the system, did not support the dominant ideology actively.

It may be noted by analysing changes during the post-Stalinist period that little by little ideology became 'hollow' practice. The shadow economy and the increasing deficit filled the environment of those times with indifference. The use of the definition of real socialism actually meant the acknowledgement that socialism under the conditions of Soviet regime could hardly be otherwise. It was de facto recognition that ambitions based on ideology were loosing their previous meaning, even though on the formal level they retained form as priorities and rituals. Alexei Yurchak defines this status as perfor- 
mative shift ${ }^{16}$, when demonstrating non-decreasing attention to the ideological rules, rituals and plans; interpretation, therefore, on the everyday life level increases, leading to the possibility of negotiating and achieving a person's own aims. Some theoreticians define this status of the Soviet times as the feature of the system, revealing 'weak structures, but strong personal relations. ${ }^{17}$

Analyzing the environment of the writers and literature, it may be stated that application of ideology was not fully monolithic and was supported variously by cultural workers at different periods. If during the Stalinist period actually all cultural workers served as key instruments of communication for legitimising the regime and its ideology, the situation changed after Stalin died. Under Khrushchev, as recognised by most presenters - representatives of the cultural nomenklatura and intelligentsia, expectations grew for a more open cultural climate. Moreover, during the period of 1954-1968 a strong shift towards cultural autonomy was observed in the republic, which was also supported by the local nomenklatura. ${ }^{18}$ As far as writers were concerned, the older generation was opposed indirectly by the younger and somewhat moderate generation, the talented representatives of which had actually taken major posts in the WU by the end of the 1960s, and such contradiction was obvious on the private level and in creation. ${ }^{19}$ Meeting of socialist standards started with the development of the trend of universalism (Mieželaitis) and psychologism (Sluckis' 'stream of consciousness'), expanding the dominating perspective of rural socialist realism, which actually became the dominating trend until the Revival Movement. Comparing the sociocultural environment of the late Soviet period, where loyalty to the ideology was gradually decreasing, with the ideological pressure that

${ }^{16}$ A. Yurchak, Everything Was Forever, Until It Was No More: The Last Soviet Generation (Princeton University Press, 2005).

${ }^{17}$ However, A. Weiner had in mind the power of the governing elite to ignore the rules and express its own interests. Assessing the late Soviet period, this principle may be expanded to wider social circles. See: A. Weiner, Making Sense of War: The Second World War and the Fate of the Bolshevik Revolution (Princeton, 2000).

${ }^{18}$ R.J. Misiūnas, R. Taagepera, Baltijos valstybès: priklausomybès metai 1940-1980 (Vilnius, 1992), p.173-179.

${ }^{19}$ E. Mieželaitis could be considered the standard-bearer of this generation. He was slightly older than the other writers of the thaw period, and, being in good standing with the party authorities, he could promote new talents alongside with himself. 
started at the end of the 1960s, the factor of informality becomes one of the key factors enabling the expression of various alternative ideas or approaches under the conditions of dogmatism, and penetrating not only through private areas, but also into the institutional environment. ${ }^{20}$

During late socialism, the intensification of localism became more prominent. Assessing the expression of local interests by the national elite in the republics of the Soviet Union, we should first of all talk about ethnic (national) patriotism or even national communism under socialist conditions by coordinating actions with the official principles of the system, and sometimes referring to backdoor actions. ${ }^{21}$ Since the Lithuanian SSR was a 'non-Russian' territory, it is important, when analysing the protection of peripheral interests, to note the response to the often hidden Soviet policy of Russification, or pay attention to the structure of the Soviet system, raising the aspect of ethno-federalism, noticing that not only the tendencies of centralization and Russification were 'sewn in' into the national area of the Soviet system, but also there was certain support with regard to ethnic and national issues. It is worth mentioning the issue of federalism and noticing that the central authority in the Soviet system created possibilities for the development of ethno-federalism leading to the formation in separate Soviet republics of ethnic elite, which, being loyal to the official policy, at the same time aimed to ensure social and economic welfare in their own countries. ${ }^{22}$ Philip Roeder applied such an authority model also to the Baltic and Caucasus Soviet republics, where local elites, being under continuous pressure from Moscow, became obliged to suppress protests of an ethnic (national) character, arising naturally from local society, or any other autonomous requirements out of tune with the official line and outside the structure of the authorities (primordialistic strategy). However, the author at the same time indicated that the activeness of such elites and attempts to implement Sovietisation policy themselves, due to problems within the existing system, makes these republics most oriented towards

${ }^{20}$ V. Ivanauskas, 'Sovietinių biurokratu darbo etika, neformalios rutinos ir planavimo sistemos trūkumai (Lietuvos atvejis)', Filosofija. Sociologija (2006, Nr. 4) p.1-11.

${ }^{21}$ W.A. Kemp Nationalism and communism in Eastern Europe and the Soviet Union (New York, 1999), p.171.

22 P.G. Roeder, 'Soviet Federalism and Ethnic Mobilization', World Politics, Vol. 23, 2 (1991), pp.196-233. 
changes leading to protests against the actions of the central authority, which violate the interests of these republics. ${ }^{23}$ The political scientist Gail Lapidus distinguishes discrepancy within the area of national relations in the USSR, declaring projections of both the prosperity of nations, and rapprochement of nations. ${ }^{24}$ However, the projection of internationalism, recording nationality in passports, the formation of Soviet republics on a national basis, and the development of culture in separate republics, were actually a resource in the Soviet republics for the expression of certain ethno-national strategies by defending their own interests with regard to the development of Russian culture.

Taking such theoretical observations to the area of the post-Stalinist literature of Lithuania and the activities of writers, it should be noted that from the 1950 s writers' attention to the issues of retaining the national heritage was increasing, including the revival of memories about authors of earlier periods, such as Maironis, Vaižgantas or Čiurlionis, as well as previous traditions that was obvious from the rhetoric at the congresses of the Writers Union in 1965 and 1970. With the help of the principle of the 'prosperity of nations', there was enough space for manoeuvring in representing the locality and for the demonstration of national achievements, whereas the clearly expressed lines of protecting the 'new subject' in the Stalinist period started fading gradually or change became more obscure and less defined (e.g. 'Žmogus' by Mieželaitis). Under such circumstances, the shift towards the retention of traditions, though with a fear of associations with bourgeois nationalism (and reasonably so, since society and intellectuals themselves quite often gave much more meaning to such heritage than just the 'blossoming of the Soviet nations'), which sometimes seemed safer than the search for new forms or abstract work, which for various ideologists primarily smelled of cosmopolitism, that is, the West.

Generations of writers, lines, circles and tensions A shift towards locality, the increased opportunities for the development of ideas and the late Soviet period context are revealed better through relations between generations (or within separate groups of writers), referring to the sources of rising tension and the instruments for suppressing

${ }^{23}$ Ibid.

${ }^{24}$ G.W. Lapidus, 'The Nationality Question and the Soviet System', Proceedings of the Academy of Political Science, Vol. 35, No. 3 (1984), p. 101. 
such conflicts related to the organisational environment of writers. It should be reasonable in analysing post-Stalinist Lithuanian literature to talk about two significant clashes of the younger generation or challenges to the dominating generation: ${ }^{25}$ The first case covers the rise of the generation of 'shestidesiatniki', and their penetration into governmental structures, while the second case is related to clashes between young modernists ('formalists') and the dominant literary circle, and the restrictions they experienced. The first case involves the generation of Marcinkevičius and Baltakis evidencing the successful integration of young writers and a more favourable cultural climate accordingly, while the second case covers the generation of Tomas Venclova, Sigitas Geda, Juozas Aputis or Marcelijus Martinaitis, restrictions of the young, and the dogmatism of Brezhnev times.

It should be noted that differences between generations were not the only source of tension. It was also conditioned by the support of different tendencies, writers' ideology, or their loyalty to the party authorities. Although such differences existed in each generation, they had particular dominant characteristics: 1) the first generation of Soviet writers - the legitimisers of the system (Cvirka, Venclova, Korsakas, Guzevičius-Gudaitis, Tilvytis ${ }^{26}$, etc.); 2) the successive post-war generation (Marcinkevičius, Baltakis) entering the writers' establishment during the Khrushchev Thaw, dissociating creative yearning from the schematic socialist tradition of realism, and coordinating it with the objectives of retaining national heritage, gradually taking up the dominating positions; 3) the generation of modernists (Geda, Aputis, Martinaitis, Kęstutis Nastopka, T. Venclova), making use of the platform developed by the older generation, while being more experimental, individualistic and indifferent to the political status quo, experiencing restriction from the regime and even control by senior colleagues (WU chiefs) during the period of the Brezhnev dogmatism.

The tightening of the regime became obvious in 1968, when dissidents were on trial in Moscow, and the rhetoric of ideologists from the centre sharpened. Subsequently, local ideologists also activated pres-

${ }^{25}$ Only such clashes of the generations were distinguished, which had a major socio-political significance, however, only some five or six generations of writers may be identified in Soviet Lithuania.

${ }^{26}$ Such authors as E. Mieželaitis, J. Baltušis, V. Reimeris, and E. Matuzevičius may be considered as the intermediate generation between the senior writers and the post-war writers. 
sure, convincing the highest authorities within the republic (e.g. Central Committee secretaries Antanas Sniečkus, Antanas Barkauskas) that 'cultural' activities should not be liberal, as this would be viewed negatively by the central authorities. In the mid-1960s Sniečkus said he did not understand culture, but did not interfere with it. However, with the increasing control of the centre and 'prompted' by Genrikas Zimanas and other ideologists, he was not ready to leave cultural development alone. ${ }^{27}$ The beginning of the tightening period coincided with several consecutive anniversaries (of Lenin, the USSR), during which nothing untoward could happen in the republic. ${ }^{28}$ The period from 1968 until 1972 may be considered as a certain time of transition, when a strict ideological range was finally settled that was not supposed to be overstepped.

In the context of the 1968 Prague events, the critic Vytautas Kubilius recorded in his diary increasing attacks on him and other writers, recalling that some 'elite' writers were at that time quick to tighten the requirements on creative work and reproach colleagues (entries of 4 April, 24 September, and 28 October of 1968). ${ }^{29}$ The sense of a tightening regime was also recorded by Bieliauskas in his diary of February 1968, writing that 'somebody in Moscow has already counted that the name of Stalin is being mentioned more often (positively, of course) in literary works. ${ }^{30}$ Being then chairman of the Writers Union, he felt moods behind the scenes very well. Bieliauskas remembered that a hostile environment towards innovation in Lithuania was felt in particular Romas Kalanta burned himself to death publicly in 1972. ${ }^{31}$ After the performance of 'Barbora Radvilaite' the director Juozas Jurašas came into conflict with the authorities, when their great dissatisfaction was aroused by the production's use of symbols. ${ }^{32}$ A performance, of Kazys Saja's play, 'Mamutų medžioklè' (Mammoth Hunt) in 1968 attracted even the attention of Moscow functionaries

${ }^{27}$ In the ideological sphere G. Zimanas was then practically the first person, shading even the LCP CC Secretary A. Barkauskas, who was responsible for the ideology. Writers stressed in their interviews that the secretary for the ideology Barkauskas obeyed G. Zimanas.

${ }^{28}$ Interview with the writer R. Sadauskas.

${ }^{29}$ V. Kubilius, Dienoraščiai. 1945-1977 (Vilnius, 2006), pp. 341-344.

${ }^{30}$ A. Bieliauskas, Abipus Rubikono: pažink savo artima (Vilnius, 2002), p. 143.

${ }^{31}$ Ibid., p. 493.

${ }^{32}$ The lowering of a banner with the picture of the Gates of Dawn at the end of the performance. See interview with the writer V. Martinkus, the chair of the LSSR Writers Union. 
and was banned because of the use of many symbols and allegories that contradicted the standards of socialist realism. ${ }^{33}$ Not incidentally, the attention of the authorities was attracted by less dogmatic magazines, such as 'Kultūros barai', 'Nemunas', 'Pergalè'. The latter two were supervised by the WU, and at one of the board meetings in 1970 attention was given to the need of strengthening the ideological aspect: 'Accept in general the plans of the magazines, suggesting that the section of publicists and critics should be strengthened, taking into account the political moment'. ${ }^{34}$

In the spring of 1972, Kubilius published an article 'Talento mislès' (Talent Puzzles) in the magazine 'Nemunas' that caused uproar among the authorities and writers. Hinting at the double morals of the poet Kostas Kubilinskas and analysing the simulation of talent, the literary critic seemed to devalue the post-war generation of writers who worked and created in the sphere of social realism. ${ }^{35}$, The case was debated on all levels: in party organisations and at the Writers Union. ${ }^{36}$ His dissertation defence was suspended for seven years. The rhetoric of writers in those times at congresses and other events witnessed that this was the way not only to demonstrate the range of creative tolerance, but also leading writers aimed thereby to teach literary criticism. For example, reproaches were voiced at the $1970 \mathrm{WU}$ Congress: 'I think no one can dispute that critics should change and improve their aesthetic views. A markedly changed literature cannot be measured by yesterday's standards. However, reckless turning of yesterday's values upside down indicates, first of all, that certain critics among us are flustered and lack integrity'. ${ }^{37}$ Another illustrative case of increased control was involved Tomas Venclova, the son of

${ }^{33}$ A. Zalatorius, Literatūra ir laisve (Vilnius, 1998), p. 66.

${ }^{34}$ Minutes of the LSSR WU Board Presidium Meeting, 29 June 1970, LMA, f. 34 , ap. 1 , b. 568 , fo. 48

${ }^{35}$ Kubilius, Dienoraščiai.

${ }^{36}$ Writers and other board members criticised at the WU Board presidium meeting of 4 April 1972 the article of V. Kubilius, passing the following decision: "Consider that the article "Talent puzzles" (1972, No 2) is tendentious in describing the development of the Soviet Lithuanian literature, distorting the living facts of the writers, which often bear an abusive and indiscreet character.' It was also announced at the same meeting that 'it was necessary to evaluate the article by V. Kubilius at the Plenary report', i.e. to escalate the issue to the upper level. See: Minutes of the WU Board Presidium Meeting, 4 Apr. 1972. LMA, f. 34, ap. 1, b. 600 , fos $68-73$.

${ }^{37}$ Speech of A. Baltakis. Minutes of the Fifth LSSR WU Congress, 27-28 May 1970, ibid., b. 566, fo. 108. 
the Soviet writer A. Venclova, when he was refused WU membership in the spring of 1971, as several board members opposed his work. It is rather interesting that of ten candidates only $\mathrm{T}$. Venclova was refused WU membership. The case is very unusual in Lithuanian literature. Venclova was raised in the social milieu of the Soviet cultural elite. He lived for some time in Moscow, where he became involved in the liberal intellectual circles, corresponded with writers such as Pasternak and Akhmatova, who were criticised by the authorities, and became a friend of the famous Russian poet Joseph Brodsky. ${ }^{38}$ As Venclova himself and his supporters recall, he was a stranger in the circles of Lithuanian writers, understood neither by ideological writers, nor by the supporters of the national line. It seems that his failure to fit in local intellectual circles and his close relations with the Moscow dissidents pushed Venclova into a more open confrontation with the system and participation in the movement for human rights. ${ }^{39}$ Because of the arising confrontation between Venclova and the authorities, in 1977 he was given permission to emigrate to the West (it seems that the standing of his deceased father was used for that). It was a mutually favourable solution both for the local authorities, unwilling to have additional trouble with Venclova, and the writer himself.

Such distrust of ideological reliability was raised against a few leaders working at the media institutions. For example, the poet Antanas Drilinga was forced to leave the post of the editor 'Nemunas', when Sniečkus' government, following the articles of Kubilius and others, recognised the 'lack of ideological message' in the journal's activities. ${ }^{40}$ Notably, the tightening of the regime influenced the restriction of activities of some other writers (Jonas Mikelinskas, J. Aputis, Jonas Juškaitis and some others ${ }^{41}$ ), when certain works that displeased the censors were 'scattered' or 'put into the drawer', even though their position did not openly oppose the authorities. More opportunities were acquired for a certain period by ideologically en-

${ }^{38}$ J. Brodskis, Poetas ir proza, ed. T. Venclova (Vilnius, 1999), p. 121.

${ }^{39}$ The famous Russian dissident N. Alekseieva recalls that upon her arrival in Lithuania in the mid1970s T. Venclova was among her key supporters on human rights issues and in trying to set up Helsinki groups. See: L. Alekseieva, P. Goldberg, Pokolenie ottepeli (Moscow, 2006).

${ }^{40}$ A. Drilinga Aš juos mylejau. Atsiminimai (Vilnius, 2005).

${ }^{41}$ The literary critic A. Zalatorius stated that such writers and poets as J. Aputis, S. Geda, J. Juškaitis and M. Martinaitis, who did not criticise the existing situation did not glorify it either: 'everybody understood that they were totally unacceptable to the official ideology'. See: Zalatorius, Literatūra, p. 65. 
gaged writers, who were pushed into top posts, such as. Vytautas Radaitis, Jonas Macevičius and partly Bieliauskas. The authorities placed confidence in them and supported their position both in WU and when performing any other important duties. Actually, these writers contributed considerably to the control of literature and writers in 1968-1972, when essential action was taken regarding restrictions on the activities of certain writers. However, when Bieliauskas left the post of WU chief, the literary environment took on a rather 'moderate' line of writers capable of fitting in with ideological leaders and party authorities (Maldonis, Marcinkevičius, Bubnys, Pocius, Baltakis, and so on), although they compromised and exhibited notably more closed 'conservative' behaviour. They tried to raise issues based on national values. During times of cultural inadequacy, the works of Just. Marcinkevičius acquired a symbolic meaning and were of great importance. However, considering the status of Just. Marcinkevičius, and the fact that such 'patriotic expression' seemed less dangerous to the authorities than liberal ideas, the form of national romanticism chosen by Just. Marcinkevičius for disclosing historical topics and presented by the distinguished writer could be fitted into the ideological framework of the 'flowering of the nation' (Rus. rastsvet). However, its radical success lay in that it disclosed public need for national historic topics in Lithuanian literature: By the end of the play 'Mažvydas' at the National Drama Theatre even in those times the audience would stand up and chant 'Lietuva, Lietuva' together with the actors. ${ }^{42}$

The said group guaranteed the 'inside management of problems' to Lithuanian party authorities, ensuring that unsuitable work would be restricted, so as not to attract the attention of Moscow with regard to the activities of writers and local problems, disassociating from the "voices of protest" (the concept of P. Roeder). Such trimming is demonstrated clearly by the restrictions on the above mentioned young writers and by the explicitly pointed rhetoric at congresses, Board meetings or plenums, e.g. at the Fifth Congress of the Writers of Soviet Lithuania held on 27 and 28 May $1970^{43}$, as well as at the

${ }^{42}$ Interview with V. Bubnys. Without discussing the artistic meaning of Marcinkevičius' work demonstrated a rather clear orientation of a certain part of the local intelligentsia towards the enhancement of national identity, trying not to provoke the local authorities by observing the position of 'domesticating' them. The authority of the republic was afraid to reject or to approve the said dramas, and according to V. Bubnys, were just sitting with clenched teeth.

${ }^{43}$ Minutes of the Fifth LSSR Writers' Congress, 27-28 May 1970, LMA, f. 34. ap. 1, b. 566 . 
session of 15 January 1974 of the Secretariat of the Writers Union of the USSR, where the issues related to the Lithuanian literature of the ninth five-year plan were discussed. At the 1970 congress, the conservatives dissociated themselves from poets and writers of the younger generation. It seems that being aware of the requirements from the centre and anticipating competition or the rise of a new world outlook, they aimed at defining the "proper behaviour" to be observed by writers, even if they favoured the application of modern creative forms themselves. While party ideologists mentioned aspects of creative expression which caused them difficulties (LCP CC representative Šimkus stressed that 'writers' attention should be directed primarily towards the working and creative Soviet people ${ }^{44}$ )', top WU leaders addressed direct hints to criticised persons. For example, the WU chairman simultaneously praised and blamed Mikelinskas, Aputis and Lankauskas, as e.g. 'despite a strong attempt of the author [Mikelinskas] and very good intentions, he does not always succeed in getting above the young and unformed heroes of the novel, in particular, where the author tries to get closer to social problems and class issues'. ${ }^{45}$ The editor of 'Pergalè' Baltakis mentioned that 'we cannot cease being concerned about a certain section of young people, who are contaminated with unhealthy tendencies of nihilism, and disdain contemporary classical Soviet literature, considering that real creativity starts from them. Even Just. Marcinkevičius, who was very creative within the present period, and who was for a long time and still is the cult figure of the youth, according to the opinion of some of our young geniuses, is a hopelessly outdated poet. It would be ridiculous, if it were not sad'. ${ }^{46}$ Similar criticism was expressed by Bubnys, Antanas Jonynas and others.

The attitude to young Lithuanian poets as talented, but clearly problematic persons, was settled finally at the 1974 USSR WU Secretariat Meeting and circulated at central level. The famous Soviet poet Robert Rozhdestvesnkii, who was close to the circle of Baltakis, particularly supported the circle of his friends, mentioning at the above WU meeting that 'it was no accident that Tikhonov called Baltakis an old writer, since this generation is retreating in bronze colours, as it raises important and great topics, without going into details, and

\footnotetext{
${ }^{44}$ Ibid., fo. 12.

${ }^{45}$ Ibid., fos 35-39.

46 Ibid., fo. 105 .
} 
is not just creating, but doing it with passion'. ${ }^{47} \mathrm{He}$ draws attention to the fact that Lithuanian émigrés were talking continuously about the Russification of Soviet peoples, stating that Lithuanian literature reveals the opposite process, referring to Mieželaitis, leading to the emulation of Mieželaitis by the young Russian poets. Stating that Sluckis and Avyžius also made a considerable influence on the prose of young writers, he mentioned that "the topicality and passion of the young Lithuanian poets are not that solid as those of the "old" Baltakis and his companions!' Baltakis, speaking at the same session, stressed the achievements of Avyžius, Sluckis, Bieliauskas, and Baltušis, and mentioned a great step forward taken by Mieželaitis, who started writing lyrical poems (followed by Just. Marcinkevičius, Janina Degutyte, Paulius Širvys, Jonas Maldonis), also referring to the patriarchs (Putinas, Venclova, Žukauskas, Macevičius, Jonynas). ${ }^{48}$ He reiterated in his speech that the critique expressed some years earlier with regard to books by Venclova, Geda, Juškaitis was fair, revealing the tendencies of aesthetics, hermetic and remote attitude towards public issues. He mentioned also that controversy initiated with regard to the creation of such undoubtedly talented individuals became not only the literary dispute, but also a misleading path for some gifted young people getting away from the impact of ideology, since certain mistakes had been made too earlier by the older generation. He mentioned that 'Geda, Juškaitis, the prose writer Aputis and other writers of this generation, the so-called young ones appeared at the time when the theory and practice of vulgar sociologisation actually departed, when a new climate, more favourable for creative yearning, settled in our lives. Our literature flourished in this period. Most writers, who experienced difficulties and went through a hard school of life and literature, used the situation with responsibility; while the youth did not experience such a school of life, and thus thought it necessary to view all creative work, irrespective of what it might be, even though they seek to revise the principles of our literature - the party line and national identity.'

It is worth mentioning the transformation of $\mathrm{WU}$, referring apart from the official requirements in the management, to the observable grouping of writers and their influence on public opinion. WU gradually became a place for the leading circle to express positions and

${ }^{47}$ Minutes of the meeting of the USSR WU Secretariat, 15 Jan. 1974, RGALI, f. 631 , op. 30 , d. 1609 , fos $78-80$.

${ }^{48}$ Ibid., fos 88-99. 
subjective interpretations as well mutual support, while officially observing set boundaries. Such an example of privatisation indicates that a certain part of informal communication and informal public areas' were not outside, but inside the institutions ${ }^{49}$.

Informal communication between writers materialised through various circles, gatherings at the house of one or another writer, the bohemian environment, and places of interest, while the grouping itself was based more on the differences between the generations, along with the creative lines and tendencies, and the status in the establishment of the authorities. The culture of kruzhki (circles) within the writers' establishment at the central level was relevant even in tsarist times. Subsequently, it became particularly important in the Soviet system as well for ensuring competition between the clusters, leadership and patronage. ${ }^{50}$ In the case of Lithuania, it explains the close relationship between different lines, while overlapping and reducing locally tensions and stigmatism between various groups of writers.

Firstly, I shall discuss the grouping dynamics of local writers. Irrespective of membership, the status of writers was quite different. The circle of leading writers used to be settled during all periods of the Soviet regime. They were not only supposed to implement Soviet indoctrination in their works, but like the authorities they were supposed to participate in various rituals of Soviet life along with party leaders, such as the celebration of various public events in the Soviet Union, the birthdays of top leaders, death anniversaries, or the opening of memorial places.

The group of writers, who had returned from Russia (the Muscovite group) was among the most prominent in the environment of the post war authorities, while from the 1950s and 1960s increasing influence in the literary environment was enjoyed by such writers as Baltakis, Maldonis, Just .Marcinkevičius and Sluckis, who received higher education in the post-war period, and were protected by Mieželaitis, the then WU chairman. ${ }^{51}$ Although the Writers Union was the institutional core of writers, the expression of informality in

${ }^{49}$ V. Klumbys, 'Lietuvos kultūrinio elito elgsenos modeliai Sovietmečiu'. Unpublished doctoral dissertation, Vilnius University, 2009.

${ }^{50}$ B. Walker, 'Kruzhok Culture: The Meaning of Patronage in the Early Soviet Literary World', Contemporary European History, Vol. 11, No. 1, Special Issue: Patronage, Personal Networks and the Party-State: Everyday Life in the Cultural Sphere in Communist Russia and East Central Europe (2002), pp. 107-123.

${ }^{51}$ A. Baltakis, Gimiau pačiu laiku. Iš dienoraščiu 1960-1997 (Vilnius, 2008). 
the environment of writers was also valid: various clusters of writers and poets were forming up, differently treating the mission of writers in the Soviet system - firstly, their ideology was different, secondly, bohemian life style was characteristic of the literary environment, which partly neutralised the ideological engagement of writers and helped in mitigating hierarchical relations between writers. Considering the stagnation of official structures in the late Soviet period and the increasing importance of personal relations, informality often became the "wedge" in the indoctrination activities of a writer.

The literary environment encompassed both leading and opposition groups, which formed separate internal groups and certain social networks through participation in WU rituals, and the different ways in which members made their career and explored their creative tendencies. However, even if it is possible to identify separate groups who communicated with one another, in comparison with technocrats, writers were not loyal companions, and were not easily squeezed into clearly defined identity frameworks (there are not many outstanding examples of stable communication throughout the entire Soviet period; one of them was a group of three poets - Baltakis, Marcinkevičius, and Maldonis, who had been fellow students of the same age). A writer as an artist was a multi-edged personality and sparingly related his identity with collective goals; his values were formed not only by ideological institutional objectives or the imposed scheme of socialist realism, but also through individual views of an artist and yearnings, phenomenological memory and even the reasons for everyday life and gaining social status (e.g. the relations and conflicts of Baltušis with Boruta, Baltakis and Mieželaitis ${ }^{52}$, as well as the friendship or estrangement between Geda and Martinaitis ${ }^{53}$ ). The concept of 'them and us' in separate circles was changing. Before his election to the post of WU chairman Bieliauskas was in Mieželaitis' circle, but, after his overturn he was regarded clearly as a 'stranger' by Baltakis, Maldonis and Mieželaitis, and related more with the ideologists. Similarly, the relationship between Mieželaitis and Baltakis also changed, even though they were in the same environment. However, at the beginning of the 1970s they were not always very much insiders in a closer circle, expressing different opinions on various issues, but after some time a mutual rapprochement could be seen

\footnotetext{
${ }^{52}$ Interview with A. Baltakis.

${ }^{53}$ Interview with M. Martinaitis.
} 
again. ${ }^{54}$ On the other hand, it is not possible to deny the influence of writers' groups, since the organisational form, existing rituals and the will of an artist to expand the set range of socialist realism, forced writers to look for creative associates and escape together from overly strict formal requirements and the façade type of Soviet life. You can trace informal clusters and meeting venues in the memoirs of writers. Bubnys remembers poets of the younger generation as a more open group: 'Let's say Martinaitis. He belongs to a different circle - more open - of Martinaitis, Geda'. ${ }^{55}$ Martinaitis himself stressed that communication between writers and cultural workers used to be transferred into various bohemian clusters or gatherings and closed meetings, 'which allowed them to get out of the system .... Such gatherings were mostly closed, with wine and coffee, but that does not mean they were just drinking. These were gatherings, where an individual could open up.' For example, he recalls that the 'bohemians' were stratified, where the elite and other more official writers and other cultural workers used to meet in the Neringa café, where along with famous writers prominent artists such as Stasys Krasauskas and Konstantinas Bogdanas used to come, too. Baltakis remembers the red 'bohemians', consisting of Jonynas, Vladas Grybas and some other pro-communist writers. Quite a few sources refer to the continuous gatherings of the circle of Baltakis, Maldonis, Just. Marcinkevičius and Stasys Krasauskas in Neringa.

'Everyone knew everyone else' in the Vilnius intellectual milieu and communicated among themselves in certain areas. However, a continuous regrouping was taking place inside, and the impact of the network was among the key factors defining the selection of an intellectual. Nevertheless, cultural workers were less consistent (than technocrats, for example), because of typical bohemian inconsistency as well as because of the experienced discoveries and disappointments through ideological activities, which could be observed in groups (if sharing empathy, as e.g. in the circle of Irena Kostkevičiūtè) and individually (notably, from the beginning of the1970s Just. Marcinkevičius was less ready to participate in official events than his companions), yet cultural workers were discovering by themselves certain negative observations about the surrounding Soviet reality. There was some consistency, nonetheless, where certain clusters were well-established

\footnotetext{
${ }^{54}$ Interview with A. Baltakis.

${ }^{55}$ Interview with V. Bubnys.
} 
with prevailing old family ties, dominating links with intellectual circles from the pre-war period (such as the circles of Meile Lukšiené, V. Zaborskaité; the Landsbergis, Jablonskis and Čiurlionis families etc.).

Talking about the influence of the circles it should be noted that they created the possibility of negotiating for those who could contact decision takers or administrators (e.g. the former WU Chairman mentioned that some Glavlit leaders could be approached more easily ${ }^{56}$ ). Some relevant circles always dominated the Writers Union. They usually became if not just the axis for personal communication to separate writers and poets, then at least the creative line, which was followed also by less communicative authors, observing an individual position. The influence of networks was related not only with the creative talent of their members, but with the characteristic accessibility to the controlling institutions. Some networks were based on nomenklatura and active personal contacts with representatives of the authorities not only at the Lithuanian level, but also at the allunion level as well. This is obviously demonstrated in the lists of local writers participating in certain USSR WU sessions. Such authors as Mieželaitis, Baltakis, Maldonis and Baltušis enjoyed particularly favourable opportunities.

Dependence on the nomenklatura influenced also future status, trust and support by the authorities. Opportunities opened too for other authors to join the network, who could become privileged without taking up a nomenklatura post (such as Marcinkevičius and Baltušis). In the Lithuanian example they had access to top leaders of the authorities, participated in various events related with their funerals, anniversaries and other rituals and were also invited to be publicly present on different important occasions. ${ }^{57}$ From the end of the 1960s until the mid-1980s, after the death of Tilvytis, Guzevičius and Venclova Sr, the circle of the leading writers and managers had more or less stabilized: Reimeris, Kazys Ambrasas, Mieželaitis, Just. Marcinkevičius, Macevičius, Maldonis, Baltakis, Radaitis, Bieliauskas, Bubnys, Pocius and some other authors. They were frag-

${ }^{56}$ Interview with Alfonsas Maldonis.

${ }^{57} \mathrm{~V}$. Bubnys, as the deputy chairman of the union, was invited to the 60th aniversary of Petras Griškevičius. See: V. Bubnys, Tolimi artimi. At(si)verrimai. (Vilnius, 2008), pp. 130-131. 
mented into several separate clusters, where closer personal communication took place. Actually two leading and competing factions within the literary leadership settled: the group of ideologists and a rather moderate group of conservative writers supporting a tendency towards ethnic nostalgia. ${ }^{58}$ Meanwhile the young modernists (the network of Juškaitis, Geda and Martinaitis, Aputis) had no access to the party leadership. It should be noted that writer networks crisscrossed within a narrow area, and this became an important factor in reducing tension between groups of writers, enhancing the feeling of local belonging, and as a specific configuration in the WU environment, where the late Soviet period revealed: 1) the expression of local ethnic nostalgia, while criticising manifestations of individualism; 2) balance between the restriction and support of young writers, aimed at retaining them within the official establishment and reducing their 'involvement' in illegal-informal practices ${ }^{59} ; 3$ ) opening of the space for the mobilisation of the national identity within cultural institutions. At the WU Congress in 1970, apart from criticising the young authors, Baltakis defined the aspiration for localism and the wish to achieve higher homogeneity of inside opinions: 'Our republic is small, and our circle of writers is narrow. I think we have all opportunities to know and understand each other well. We should not let an unhealthy spirit of alienation into our collective. I assume that our congress will contribute to the further consolidation of Soviet Lithuanian literature'. ${ }^{60}$ Although it was obvious that consolidation would follow rules set by their generation, this was quite significant for overcoming antagonism and settling dominant views within the WU environment. Informal communication in network meeting places (such as the Neringa and Palanga restaurants) opened opportunities for improving relations, and sometimes even uncovered motivations. The literary critic K. Nastopka, who belonged to the bohemian environment of the restricted writers (together with Aputis, Geda and some others), remembered that sometimes Baltakis also showed up in

${ }^{58} \mathrm{~V}$. Ivanauskas, 'Sovietinis režimas ir kultūrinès nomenklatūros kaita vèlyvuoju Sovietmečiu Lietuvoje. Rašytojų aplinkos atvejis’, Politologija, (2010, 4 (60)), pp. 53-84.

${ }^{59}$ Only T. Venclova expressed more open dissociation from the local environment of writers, who did not agree to compromises, and was not admitted to the WU in 1972.

${ }^{60}$ Minutes of the Fifth Congress of the Writers of the LSSR, 27-28 May 1970, LMA, f. 34. ap. 1, b. 566, fo. 109. 
their environment, and after some complicated situations talked that he and his colleagues protected them from major problems, as if it were good for the young ones, since they did not have to take responsibility and could say anything they wished. Bubnys stressed in his interview that some official decisions were just obligatory performance of the given roles: 'Someone was supposed to rule, someone was supposed to take the lead, and someone was supposed to labour. Would it be better, if there were untalented people...? ${ }^{\prime 61}$ All this, however, did not determine the main direction of the course. It may be stated that such authors as Martinaitis, Geda or Aputis, Mikelinskas were able find their niche within the literary scene and within the establishment of writers, published their books and in the long run were recognised by the authorities and received awards. Martinaitis became closer to the circle of Just. Marcinkevičius and was integrated into the circle of poets who represented poets at various official events. Restrictions on the literary critic V. Kubilius were reduced with the time as well. In the case of control, Aesopian language was used: Martinaitis published his 'Kukučio baladès', Saja wrote absurd dramas, and Geda expressed archaic nostalgia and a mixture of different forms in his works. Separate authors also participated in protecting monuments (for example, the Garage Initiative of the1970s), though in practice they were all official WU members and did not openly oppose socialist realism or position themselves as dissidents. On the other side, assessing the impact of the majority both from the generation of Just. Marcinkevičius, and Geda, there were no doubts concerning the shift towards the enhancement of national identity overstepping the principles of the 'flowering of nations'. A certain shift in the role of a writer (along with WU) may be illustrated by the observations of Just. Marcinkevičias in 1980 while discussing the role of literature and the writer: 'The writer is perhaps the most active watcher of the national culture, a particular transformer of its heritage into the present and into the future'. ${ }^{62}$

Conclusions In the late Soviet period, the Writers Union changed in comparison with the early period of its activities during the Stalin regime. Competition between generations and the onset of the decline of the Soviet system provided a wider variety of ideas than in the Sta-

${ }^{61}$ Interview with V. Bubnys.

62 J. Marcinkevičius, 'Dienoraštis be datu', Pergale, 1980, Nr. 3, p. 96. 
linist period. Leading WU writers in the 1960s and 1970s were considerably less ideological than their predecessors, and the development and the dissemination of national images occupied much more space among the communist values.

The friction that started between the senior generation of Baltakis, Marcinkevičius and that of Geda, Aputis was determined primarily by the changed times. However, there was also natural competition between the generations for leadership in the literary establishment and at the same time finding the scope for seeking creative goals. The existing configuration of WU, wherein the senior generation took advantage until the establishment of the Sajūdis movement, also meant wider possibilities for national ideology in comparison with individual expression. Such a model of professional adaptation allowed even writers subject to restriction to find opportunities to survive within official structures through certain compromises, thereby refraining from involvement in dissident activities or 'samizdat' publications. They were able to disseminate alternative ideas, often in line with national ideology by using Aesopian language, and informal initiatives and communications.

As a system WU accepted both conformism and partial escape (manoeuvring). The system as such had a strong mechanism of control, which was operational in protecting not only ideological goals, but also local objectives, and under the impact of dominating private circles it opened possibilities also for the dissemination of risky (for the writers) ideas, if a proper form was found in the official procedures, ensuring thus certain dynamics within the context of dogmatic requirements of the authorities.

\section{Author Details}

Vilius Ivanauskas (born 1979) a post-doctoral researcher at the Institute of International Relations and Political Sciences, Vilnius University, wrote his dissertation on The Lithuanian nomenklatura in the bureaucratic system: between stagnation and dynamics (1970-1988). This article was prepared while carrying out post-doctoral research on Features of cultural workers' activities in the late Soviet period: between obligations to the regime and the establishment of the Sajüdis.

Address: VU TSPMI, Vokiečiu g. 10, Vilnius LT-01130

Email: vilius.ivanauskas@gmail.com 


\section{RAŠYTOJŲ SĄJUNGA SOVIETINĖJE LIETUVOJE VĖLYVUOJU SOVIETMEČIU: VIETA KONFORMIZMUI AR PABĖGIMUI}

Santrauka

\section{VILIUS IVANAUSKAS}

Straipsnyje nagrinejjama, kaip pasikeite Lietuvos TSR rašytojų sajungos vaidmuo vélyvuoju sovietmečiu, palyginti su ankstesniu periodu, - omenyje turimos besikeičiančios dominuojančios rašytojų nuostatos ir tai, kaip šias nuostatas skatino, maskuodavo ar varžydavo Rašytojų sajunga, rašytojų aplinkos establišmentas per planavimo, kontrolès ir net buitinio saugumo kūrimo mechanizmus. Autorius daro išvadą, kad vėlyvuoju sovietmečiu Rašytojų sajunga buvo pasikeitusi, palyginti su stalinizmo laikotarpiu, o reikšmingiausi rašytojai 7-8 dešimtmetyje buvo kur kas mažiau ideologiški nei ju pirmtakai, šalia komunistinių vetybių sklaidos vis svarbesni vaidmeni vaidino nacionalinių vaizdinių plètojimas ir sklaida. Rašytojų sajungoje kaip sistemoje buvo vietos ir konformizmui, ir daliniam pabègimui (manevravimui). Nors ji turejjo stiprų kontrolès mechanizmą, vis dèlto garantavo tokị rašytoju adaptacijos modelị, kai net ir suvaržymus patiriantys rašytojai turèjo galimybių išlikti oficialiojoje struktūroje darydami kai kuriuos kompomisus ir iš esmès susilaikydami nuo įsitraukimo į disidentinę veiklą ar samizdato leidybą. 